\title{
RESEARCH PAPER \\ Induction of direct organogenesis from aerial explants of scented alstroemeria genotypes
}

\author{
Camila Guzmán, Loreto Prat, Constanza Rivas, and Danilo Aros \\ Universidad de Chile, Facultad de Ciencias Agronómicas. Santa Rosa 11315, La Pintana, Santiago, Chile.
}

\begin{abstract}
C. Guzmán, L. Prat, C. Rivas, and D. Aros. 2018. Induction of direct organogenesis from aerial explants of scented alstroemeria genotypes. Cien. Inv. Agr. 45(2):158-168. Alstroemeria is an important pot plant and cut flower in the ornamental plant market, and its propagation mainly occurs by rhizome division. However, this method is inefficient and timeconsuming and may contribute to the spread of viruses. This study focused on developing in vitro propagation protocols using aerial explants of Alstroemeria caryophyllaea and A. 'Sweet Laura', two scented genotypes. Aerial explants of alstroemeria were regenerated by testing three types of aerial explants and four concentrations of cytokinins. Both A. caryophyllaea and $A$. 'Sweet Laura' showed the highest induction rate from shoots, with values of 35 and $63.3 \%$, respectively. For both genotypes, the optimum BAP concentration for direct organogenesis from buds was $1.0 \mathrm{mg} \mathrm{L}^{-1}$. Finally, a successful protocol for in vitro propagation of $A$. caryophyllaea and $A$. 'Sweet Laura' through direct organogenesis from aerial explants was generated.
\end{abstract}

Keywords: Alstroemeria caryophyllaea, Alstroemeria 'Sweet Laura', growth regulators, tissue culture.

Abbreviations: BAP - 6-benzylaminopurine; MS - Murashige and Skoog (1962) medium.

\section{Introduction}

Alstroemeria is a rhizomatous monocot native to South America belonging to the Alstroemeriaceae family (Bayer, 1987; Muñoz and Moreira, 2003). Many varieties have been developed through breeding techniques, such as mutagenesis (Przybyla, 2000; Aros et al., 2012a), polyploidization ( $\mathrm{Lu}$ and Bridgen, 1997; Takayuki, 1999) and mainly interspecific hybridization (Burchi et al., 1997). Currently, this species represents an important pot plant and cut flower in the ornamental plant

Received Jan 04, 2018. Accepted Jun 05, 2018.

Corresponding author: daros@uchile.cl market due to its attractive flowers and long vase life (Hoshino, 2008). Alstroemeria is commonly vegetatively propagated by rhizome division. However, this system of propagation is inefficient and time-consuming (Lin et al., 1997) and may contribute to the spread of viruses affecting yield during cultivation (Van Zaayen, 1995).

In vitro micropropagation is a frequently used alternative to propagate alstroemeria hybrids (Khaleghi et al., 2008) and native species (Aros et al., 2017), and several studies have validated the efficiency of this technique (Chiari and Bridgen 2000; Khaleghi et al., 2008). Most studies assessing in vitro propagation of alstroemeria have 
been performed using sections of rhizome as the explant (Yousef et al. 2007; Pumisutapon et al., 2011; Aros et al., 2017), but a low multiplication rate was often observed (Lin et al., 1998). In vitro propagation of alstroemeria through immature (Van Schaik et al., 1996) and mature embryos (Hutchinson et al., 1994) has also been reported, showing a high multiplication rate, particularly when an embryogenic callus was induced (Akutsu and Sato, 2002; Kim et al., 2006). However, this method is not useful for clonal propagation of commercial varieties. More recently, studies have been conducted on micropropagation from aerial explants, such as floral apices (Pedraza-Santos et al., 2006), nodes with axil tissue (Kim et al., 2006) and leaf base (Nasri et al., 2013). Organs such as leaves and stems for use as explants show several advantages for in vitro propagation because they provide more material for propagation than rhizomes, and aerial explants potentially present less contamination than underground explants (Lin et al., 1998).

In addition to the type of explant, several other factors are involved in in vitro propagation. The effect and interaction of growth regulators in particular on the in vitro propagation of alstroemeria have been widely studied (Lin et al., 1997; Cruz et al., 2003; Hamidoghli et al., 2007), and these studies mainly focused on the interaction between auxin and cytokinin concentrations to improve shoot regeneration from the explants (Pedraza-Santos, 2006; Ongaro and Leyser, 2008). Moreover, the effect of photoperiod and temperature during in vitro propagation of alstroemeria has also been reported (Cruz et al., 2003; Pedraza-Santos et al., 2006).

Each genotype has its own multiplication rate when cultured and propagated in vitro (Lu and Bridgen, 1996; Chiari and Bridgen, 2000; Hoshino, 2008). Furthermore, this character is typically considered a selection criterion in breeding programs when a new variety is released. Therefore, specific in vitro propagation protocols are needed for each genotype studied. Considering that floral scent has not been targeted as an important trait in alstroemeria breeding programs (Aros et al., 2012b; Aros et al., 2015), little is known about the propagation of fragrant genotypes. This study aimed at developing an efficient protocol of in vitro propagation for two scented alstroemeria genotypes: the Brazilian species Alstroemeria caryophyllaea and Alstroemeria 'Sweet Laura', which was obtained by crossing Alstroemeria aurea $\mathrm{x}$ A. caryophyllaea (Bridgen et al. 2009). The effects of aerial explants from different organs and the concentration of cytokinins (6-benzylaminopurine; BAP) in the culture media were evaluated to optimize the micropropagation of these two genotypes.

\section{Materials And Methods}

\section{Plant material}

Aerial explants were collected from selected lines of Alstroemeria caryophyllaea (Alstroemeria Breeding Program at the University of Chile) and Alstroemeria 'Sweet Laura' (Alstroemeria Breeding Program at Cornell University), which were both grown under greenhouse conditions at the Faculty of Agricultural Sciences, University of Chile. Three types of aerial explants were evaluated: leaves (obtained from the apical zone of the plant), young shoots ( $1 \mathrm{~cm}$ long without extended leaves) and stem sections (1 cm long containing an axillary bud). Explants were disinfected by immersion in $0.9 \% \mathrm{NaOCl}$ (15 min), followed by rinsing $(3 \mathrm{~min})$ three times using distilled sterilized water.

\section{Explant induction}

Twenty-four treatments resulting from the combination of three explants (shoot, leaf, stem), four concentrations of cytokinin $(0.0,0.5,1.0$ and 2.0 $\mathrm{mg} \mathrm{L}^{-1}$ of BAP) and two genotypes (Alstroemeria caryophyllaea and $A$. 'Sweet Laura') were assessed in a completely randomized factorial design. 
Fifteen replicates per treatment were performed, and the experimental unit consisted of one explant cultured in a Petri dish (disposable, $60 \times 15 \mathrm{~mm}$ ) containing $20 \mathrm{ml}$ of MS medium (Murashige and Skoog, 1962), $30 \mathrm{~g} \mathrm{~L}^{-1}$ sucrose, and $7 \mathrm{~g} \mathrm{~L}^{-1}$ agar, with the $\mathrm{pH}$ adjusted to 5.8. The medium was supplemented with $0.1 \mathrm{mg} \mathrm{L}^{-1}$ indolebutyric acid (IBA) in combination with the different concentrations of BAP as previously described. In vitro explants were grown under controlled conditions of a photoperiod of 16/8 hours light/dark (regime provided by lamps with density photosynthetic photon flux of $900 \mathrm{~mol}$ photons $\mathrm{m}^{-2} \mathrm{~s}^{-1}$ ) and 20 ${ }^{\circ} \mathrm{C}$. After 4 weeks, induced explants (explants showing a $1 \mathrm{~mm}$ growth) were transferred to the regeneration medium. The percentage of explants exhibiting oxidation, contamination and callus development was also recorded.

\section{Explant regeneration}

Induced explants were transferred to test tubes $(15 \times 100 \mathrm{~mm})$ containing $10 \mathrm{ml}$ of liquid medium with MS and $30 \mathrm{~g} \mathrm{~L}^{-1}$ sucrose supplemented with $2 \mathrm{mg} \mathrm{L}^{-1} \mathrm{BAP}$, and the $\mathrm{pH}$ was adjusted to 5.8. The explants were grown under the same controlled conditions described previously. After 8 weeks, the number of regenerated shoots per explant, the length and width $(\mathrm{cm})$ of regenerated shoots, the number of regenerated leaves per explant, and the length and width $(\mathrm{cm})$ of regenerated leaves were evaluated in regenerated explants.

\section{Histological study}

To determine the meristematic zone from which organogenesis was induced, transverse histological sections were obtained from samples of induced leaf petiole of Alstroemeria 'Sweet Laura'. Samples were obtained at days 0 and 7 from in vitro cultivation based on the methodology described by Prat et al. (2008). Samples were fixed in a solution of FAA (4\% formalin, 70\% acetic acid, and 70\% alcohol at a ratio of 5:5:90 $\mathrm{v} / \mathrm{v})$, dehydrated in ethanol (70, 80 and $90 \%$ for 30 minutes each time), and finally infiltrated in JB4 solution (Polyscience, Inc., Warrington, PA). Using an ultramicrotome (model 1516, Leitz, Germany), sections 10 microns thick were generated, mounted on a sealed slide with Canada balsam, and stained with toluidine blue for observation under light microscopy.

\section{Statistical analysis}

Data of induced, regenerated, necrotic, contaminated explants and callus development were analyzed using the Bliss transformation (arc$\operatorname{sen} \sqrt{ } \%$ ). Logarithmic transformation of the data was applied, including evaluation of regenerated shoots. An analysis of variance was performed using Infostat software. Means were compared using Tukey's HSD (honest significant difference) test for multiple pairwise comparisons with a significance level of 0.05 .

\section{Results}

\section{Explant induction}

Induction was observed in Alstroemeria caryophyllaea shoots and leaves and $A$. 'Sweet Laura' shoots, leaves and stems. For both genotypes, shoot explants showed the highest induction rate compared with leaf and stem, with values of $63 \%$ and 35\% for $A$. 'Sweet Laura' and A. caryophyllaea, respectively. A higher induction rate of shoots and stems was observed in $A$. 'Sweet Laura', whereas no significant differences were noted between induced leaves observed in A. caryophyllaea (15\%) and $A$. 'Sweet Laura' (18.3\%) (Table 1).

Regarding the interaction between the cytokinin concentration and genotype, no significant differences were observed between genotypes except those explants cultured with $1 \mathrm{mg} \mathrm{L}^{-1} \mathrm{BAP}$, which showed a significantly higher induction rate with $A$. 'Sweet Laura' explants (64.4\%) than with $A$. 
Table 1. Induced explants observed after 4 weeks considering the interaction between genotype and type of explant $(\mathrm{n}=60)$.

\begin{tabular}{lcccccc}
\hline \multirow{2}{*}{ Genotype } & \multicolumn{5}{c}{ Induced explants (\%) } \\
\cline { 2 - 7 } & \multicolumn{2}{c}{ shoot } & \multicolumn{2}{c}{ leaf } & \multicolumn{2}{c}{ stem } \\
\hline A. caryophyllaea & 35.0 & $\mathrm{aB}$ & 15.0 & $\mathrm{bA}$ & 0.0 & $\mathrm{bB}$ \\
A. 'Sweet Laura' & 63.3 & $\mathrm{aA}$ & 18.3 & $\mathrm{bA}$ & 20.0 & $\mathrm{bA}$ \\
\hline
\end{tabular}

*Different capital letters in the column indicate significant differences according to Tukey's test $(\mathrm{P} \leq 0.05)$.

**Different small letters in the row indicate significant differences according to Tukey's test $(\mathrm{P} \leq 0.05)$.

caryophyllaea (33.3\%). In addition, $1 \mathrm{mg} \mathrm{L} \mathrm{L}^{-1} \mathrm{BAP}$ showed the highest explant induction, particularly in $A$. 'Sweet Laura', where significant differences were noted compared with the other concentrations. The lowest induction value obtained was in explants cultured without BAP supplementation in both A. caryophyllaea (4.4\%) and A. 'Sweet Laura' (11.1\%); however, significant differences were not observed with the remaining BAP concentrations applied, particularly $1 \mathrm{mg} \mathrm{L}^{-1}$ (Table 2).

Table 2. Induced explants observed after 4 weeks considering the interaction between genotype and BAP concentration $(n=60)$.

\begin{tabular}{|c|c|c|c|c|}
\hline \multirow[b]{2}{*}{ Genotype } & \multicolumn{4}{|c|}{ Induced explants (\%) } \\
\hline & $\begin{array}{c}0 \mathrm{mg} \mathrm{L}^{-1} \\
\text { BAP }\end{array}$ & $\begin{array}{c}0.5 \mathrm{mg} \\
\mathrm{L}^{-1} \mathrm{BAP}\end{array}$ & $\begin{array}{c}1.0 \mathrm{mg} \mathrm{L}^{-1} \\
\text { BAP }\end{array}$ & $\begin{array}{c}2.0 \mathrm{mg} \mathrm{L}^{-1} \\
\mathrm{BAP}\end{array}$ \\
\hline A. caryophyllaea & $4.4 \mathrm{bA}$ & 8.9 bA & $33.3 \mathrm{aB}$ & $20.0 \mathrm{abA}$ \\
\hline A. 'Sweet Laura' & $11.1 \mathrm{cA}$ & $37.8 \mathrm{bA}$ & $64.4 \mathrm{aA}$ & $22.2 \mathrm{bcA}$ \\
\hline
\end{tabular}

*Different capital letters in the column indicate significant differences according to Tukey's test $(\mathrm{P} \leq 0.05)$.

**Different small letters in the row indicate significant differences according to Tukey's test $(\mathrm{P} \leq 0.05)$.

Explant induction was concentrated during the second week for both genotypes and all the explants evaluated, particularly those growing in the medium supplemented with $1 \mathrm{mg} \mathrm{L}^{-1} \mathrm{BAP}$, where the highest number of induced explants was observed. Only shoots and stems were induced in the first week, whereas only shoots of A. caryophyllaea grown with $2.0 \mathrm{mg} \mathrm{L}^{-1} \mathrm{BAP}$ showed induction in the fourth week (Figures 1 and 2). A. caryophyllaea shoots were induced with all the BAP concentrations evaluated, whereas leaves were only induced with 1.0 and $2.0 \mathrm{mg} \mathrm{L}^{-1}$ BAP. A. 'Sweet Laura' shoots were also induced with all BAP concentrations, but the absence of this growth regulator in the culture media did not produce induction in either stems or leaves.

\section{Explant regeneration}

Direct organogenesis was observed after explant induction. Elongation of shoots and subsequent leaf development were observed during shoot regeneration. On the other hand, leaves developed new shoots from the base of the petiole, and stems showed elongation and the development of new leaves from the axillary bud.

Interactions between factors (genotype, explant and BAP concentration) were not significant. Thus, the effect of each factor on the regeneration rate was independently analyzed. The genotype

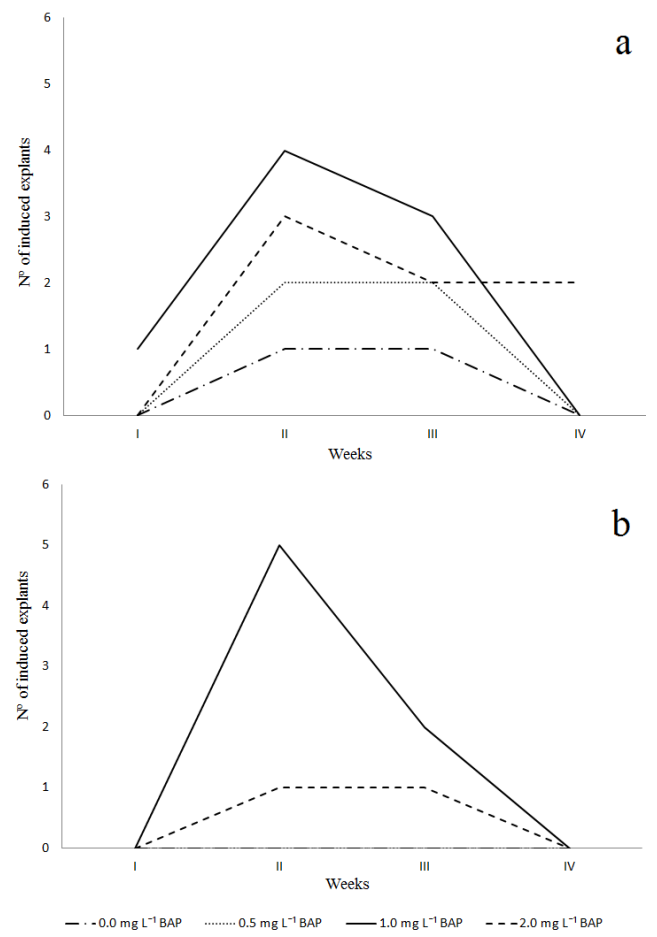

Figure 1. Induction of shoots (a) and leaves (b) of $A$. caryophyllaea in vitro cultured under different BAP concentrations for 4 weeks. 

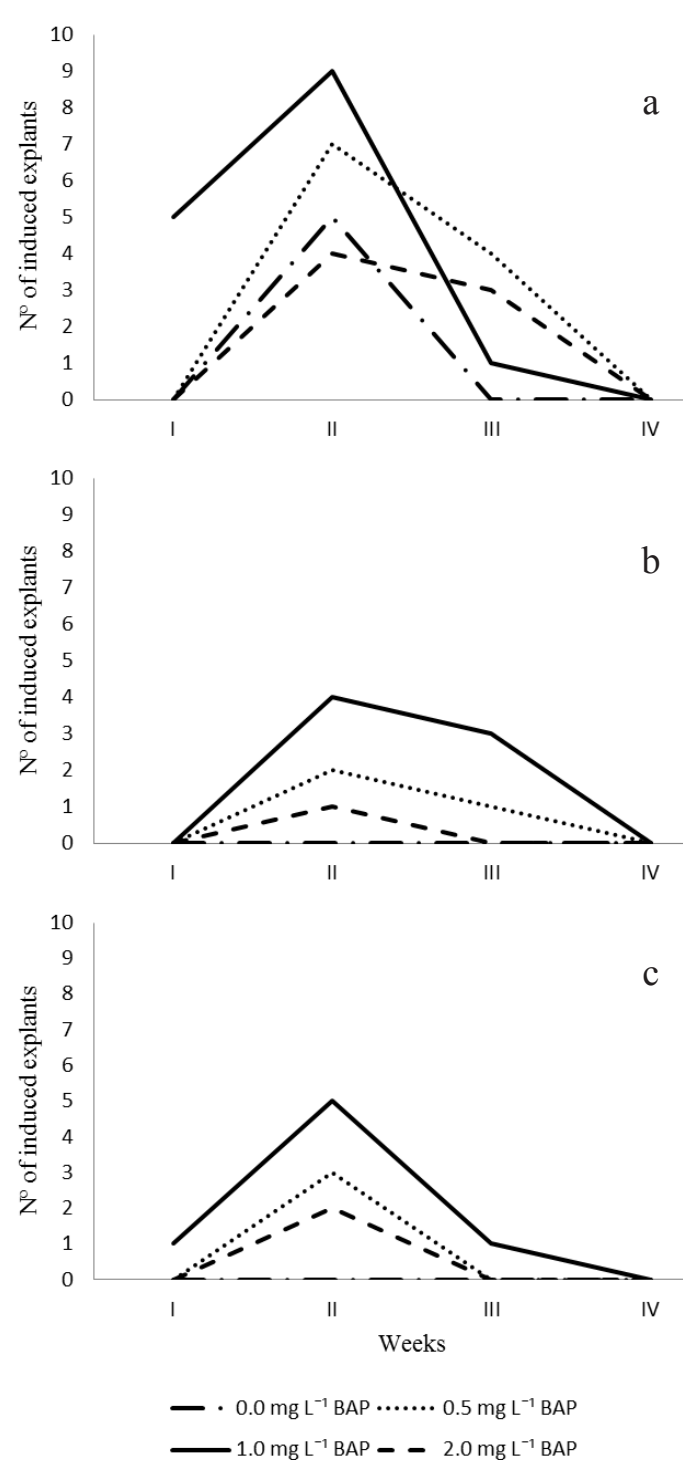

Figure 2. Induction of shoots (a), leaves (b) and stem (c) of $A$. 'Sweet Laura' in vitro cultured under different BAP concentrations for 4 weeks.

A. 'Sweet Laura' showed higher explant regeneration (21.7\%) than A. caryophyllaea (8.3\%). Regarding the explants, the shoot showed the highest regeneration (30\%), and this result was significantly different from that of leaves and stems, with $10 \%$ and $5 \%$ regeneration, respectively. As observed during induction, explants previously cultured with $1.0 \mathrm{mg} \mathrm{L}^{-1} \mathrm{BAP}$ showed significantly higher regeneration (30\%) than the other BAP concentrations evaluated (Table 3).
Table 3. Effect of genotype $(n=180)$, explants $(n=120)$ and BAP concentration $(\mathrm{n}=90)$ on the regeneration observed from aerial explants of $A$. caryophyllaea and $A$. 'Sweet Laura'.

\begin{tabular}{lccc}
\hline Treatment & & \multicolumn{2}{c}{ Regeneration (\%) } \\
\hline Genotype & A. 'Sweet Laura' & 21.7 & $\mathrm{a}$ \\
& A. caryophyllaea & 8.3 & $\mathrm{~b}$ \\
\multirow{2}{*}{ Explant } & Shoot & 30.0 & $\mathrm{a}$ \\
& Leaf & 10.0 & $\mathrm{~b}$ \\
& Stem & 5.0 & $\mathrm{~b}$ \\
BAP & 0.0 & 4.4 & $\mathrm{~b}$ \\
concentration & 0.5 & 12.2 & $\mathrm{~b}$ \\
(mg L-1) & 1.0 & 30.0 & $\mathrm{a}$ \\
& 2.0 & 13.3 & $\mathrm{~b}$ \\
\hline
\end{tabular}

*Different letters in indicate significant differences within each factor (genotype, explant and BAP concentration) according to Tukey's test $(\mathrm{P} \leq 0.05)$.

Regarding the growth of regenerated explants, the genotype showed an interaction with the type of explant with respect to the shoot length and width and leaf length. Thus, shoots presented the longest regeneration particularly in $A$. 'Sweet Laura', where the shoot length $(3.59 \mathrm{~cm})$ showed significant differences compared with shoots regenerated from leaves $(0.29 \mathrm{~cm})$ and stems $(1.01 \mathrm{~cm})$. Regenerated shoots were also wider when using the shoot as the explant $(0.18 \mathrm{~cm})$ from $A$. 'Sweet Laura'. Maximum leaf length was observed in explants obtained from shoots of $A$. caryophyllaea $(0.65 \mathrm{~cm})$ and $A$. 'Sweet Laura' $(1.62 \mathrm{~cm})$ (Table 4).

For all the growth parameters evaluated, only shoots and leaves regenerated from shoots showed significant differences when comparing both genotypes. Thus, shoots and leaves showed higher growth in $A$. 'Sweet Laura' explants (Table 4).

Concerning the number of leaves produced per shoot, interactions between factors (genotype, explant and BAP concentration) were not significant, so the factors were independently analyzed. A. 'Sweet Laura' showed more leaves per shoot (1.81) than A. caryophyllaea (0.88), while shoot explants produced the highest number of leaves per shoot (3.24). This result was significantly different compared with the number of leaves from 
Table 4. Genotype and explant effect on the growth of shoots and leaves of $A$. caryophyllaea and A. 'Sweet Laura' regenerated from aerial explants.

\begin{tabular}{|c|c|c|c|c|c|c|c|}
\hline \multirow{3}{*}{$\begin{array}{l}\text { Genotype } \\
\text { A. caryophyllaea }\end{array}$} & \multirow{3}{*}{$\begin{array}{c}\text { Explant } \\
\text { Shoot }\end{array}$} & \multicolumn{4}{|c|}{ Shoot } & \multirow{2}{*}{\multicolumn{2}{|c|}{$\begin{array}{c}\text { Leaf } \\
\text { Length }(\mathrm{cm})\end{array}$}} \\
\hline & & \multicolumn{2}{|c|}{ Length $(\mathrm{cm})$} & \multicolumn{2}{|c|}{ Width $(\mathrm{cm})$} & & \\
\hline & & 1.23 & $\mathrm{aB}$ & 0.08 & $\mathrm{aB}$ & 0.65 & $\mathrm{aB}$ \\
\hline \multirow{5}{*}{ A. 'Sweet Laura' } & Leaf & 0.85 & $\mathrm{abA}$ & 0.02 & $\mathrm{abA}$ & 0.23 & $\mathrm{aA}$ \\
\hline & Stem & 0.00 & $\mathrm{bA}$ & 0.00 & $\mathrm{bA}$ & 0.00 & $\mathrm{aA}$ \\
\hline & Shoot & 3.59 & $\mathrm{aA}$ & 0.18 & $\mathrm{aA}$ & 1.62 & $\mathrm{aA}$ \\
\hline & Leaf & 0.29 & $\mathrm{bA}$ & 0.03 & $\mathrm{bA}$ & 0.29 & $\mathrm{bA}$ \\
\hline & Stem & 1.01 & $\mathrm{bA}$ & 0.03 & $\mathrm{bA}$ & 0.73 & $\mathrm{bA}$ \\
\hline
\end{tabular}

*Different capital letters indicate significant differences between genotypes for each explant according to Tukey's test $(\mathrm{P} \leq 0.05)$.

**Different small letters indicate significant differences among explants for each genotype according to Tukey's test (P $\leq 0.05)$.

the leaf (0.17) and stem (0.63) explants. Finally, 1.0 $\mathrm{mg} \mathrm{L}{ }^{-1}$ BAP significantly increased the number of leaves per shoot, revealing significant differences compared with the remaining concentrations evaluated (Table 5).

\section{Histology}

Transverse histological sections obtained from induced leaf petiole of $A$. 'Sweet Laura' showed that explants cultured in the induction medium (supplemented with $1 \mathrm{mg} \mathrm{L}^{-1} \mathrm{BAP}$ ) at day 0 presented vascular bundles scattered in parenchyma composed of cells larger than those observed in the epidermis. Small cells with evidence of meristematic development were not observed (Figure 3A). After 7 days, the epidermal layer of the leaf petiole showed a transition to slight bumps on the surface due to the onset of meristem development, which subsequently served as the origin of new shoots by direct organogenesis (Figure 3B).

\section{Discussion}

\section{Direct organogenesis from aerial explants}

Direct organogenesis occurred in aerial explants of $A$. 'Sweet Laura' and A. caryophyllaea. Callus development was not observed, which is positive
Table 5. Effect of genotype $(n=180)$, explants $(n=120)$ and BAP concentration $(\mathrm{n}=90)$ on the number of leaves produced per shoot regenerated from aerial explants of $A$. caryophyllaea and $A$. 'Sweet Laura'.

\begin{tabular}{lccc}
\hline Treatment & & $\mathrm{N}^{\circ}$ leaves per shoot \\
\hline Genotype & A. 'Sweet Laura' & 1.81 & $\mathrm{a}$ \\
& A. caryophyllaea & 0.88 & $\mathrm{~b}$ \\
\hline Explant & Shoot & 3.24 & $\mathrm{a}$ \\
& Leaf & 0.17 & $\mathrm{~b}$ \\
& Stem & 0.63 & $\mathrm{~b}$ \\
$\begin{array}{l}\text { BAP } \\
\text { (mg L-1 }\end{array}$ & 0.0 & 0.58 & $\mathrm{~b}$ \\
& 0.5 & 1.52 & $\mathrm{~b}$ \\
& 1.0 & 4.13 & $\mathrm{a}$ \\
& 2.0 & 1.83 & $\mathrm{~b}$ \\
\hline
\end{tabular}

*Different letters in indicate significant differences within each factor (genotype, explant and BAP concentration) according to Tukey's test $(\mathrm{P} \leq 0.05)$.

for the clonal propagation of cultivars because the risk of genetic variability induction by somaclonal regeneration is reduced. This result is consistent with results obtained by Lin et al. $(1997 ; 1998)$ and Nasri et al. (2013) in alstroemeria, where callus production was not observed. Nevertheless, other studies suggested that shoots and leaves cultured in media supplemented with TDZ and IBA (Cruz et al., 2003) or BAP and KIN (Pedraza-Santos et al., 2006) tend to produce callus development 


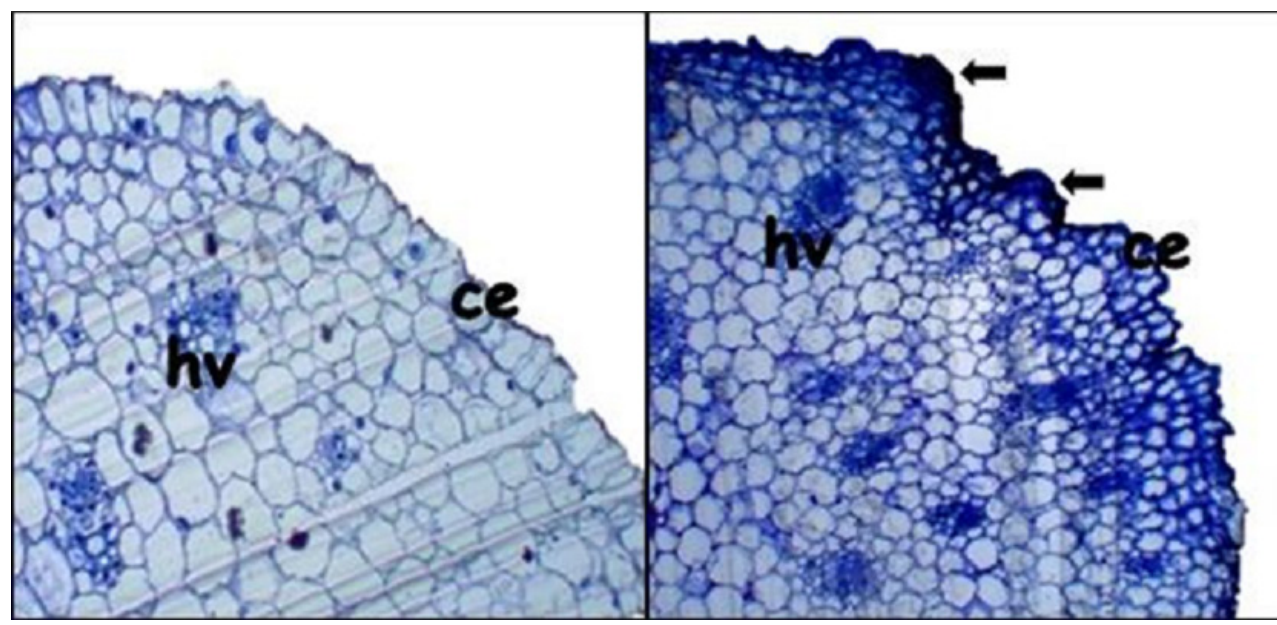

Figure 3. Transverse histological sections obtained from induced leaf petiole of A. 'Sweet Laura' at day 0 (a) and after 7 days of in vitro culture on induction medium.

*Arrows indicate bumps due to the starting of meristem development.

* ce = epidermal layer; hv = vascular bundles.

with the potential to induce somatic embryogenesis. Lin et al. (2000) observed the generation of a compact callus from nodal stem segments, while Pedraza-Santos et al. (2006) suggested that leaves and stems are explants with the potential to generate an embryogenic callus.

Direct organogenesis was observed in leaves by Lin et al. (1997) and Nasri et al. (2013) and in immature inflorescences by Pedraza-Santos et al. (2006). Regarding regeneration from leaves, Lin et al. (1997) reported similar results to those obtained in this study, observing petiole elongation and widening of the nodal zone. In addition, Lin et al. (1998) and Nasri et al. (2013) reported induction from the area between the base of the leaf and the stem. Moreover, Lin et al. (1997) suggested that the length of the petiole adhered to the leaf could affect the regeneration rate and the number of shoots induced.

\section{Induction of new shoots from aerial explants}

Only stem sections of $A$. 'Sweet Laura' were induced, whereas no induction from this explant was observed in A. caryophyllaea. Pedraza-Santos et al. (2006) failed to generate direct organogenesis from stems of Alstroemeria cv. 'Yellow King', and induction occurred only in inflorescences (40\%). However, Lin et al. (1997) observed 36\% shoot induction in leaves of Alstroemeria 'VV024'. In this study, only 15 and $18.3 \%$ induction was observed from leaves of $A$. caryophyllaea and $A$. 'Sweet Laura', respectively. However, induction from shoots reached up to $63.3 \%$ in $A$. 'Sweet Laura' (Table 1). Hence, clear effects of the genotype and the type of explant were noted when alstroemeria was propagated in vitro.

Considering the effect of growth regulators in this study, $1 \mathrm{mg} \mathrm{L}^{-1}$ BAP produced the highest induction rate regardless of the genotype and explant type used. Nasri et al. (2013) obtained similar results with explants of an Alstroemeria ligtu hybrid using supplementation with $1 \mathrm{mg}$ $\mathrm{L}^{-1} \mathrm{BAP}$ and $0.1 \mathrm{mg} \mathrm{L}^{-1}$ of AIB. By contrast, Lin et al. (1997) observed the highest explant induction of Alstroemeria 'VV024' with $2.2 \mathrm{mg} \mathrm{L}^{-1}$ TDZ. Thus, cytokinins seem to be crucial for the induction of new shoots from aerial explants of alstroemeria. Nevertheless, treatments without BAP supplementation led to induction in both A. caryophyllaea (4.4\%) and A. 'Sweet Laura' (11.1\%) (Table 2). According to related literature (George et al., 2008; Ongaro and Leyser, 2008), 
those explants that result in induction despite being grown in cytokinin-free media may reflect the effect caused by endogenous hormones.

For both genotypes, the induction rate responded positively to increasing concentrations of BAP until peaking at $1 \mathrm{mg} \mathrm{L}^{-1} \mathrm{BAP}$. Afterward, the induction rate decreased with supplementation of $2.0 \mathrm{mg} \mathrm{L}^{-1}$ BAP (Table 2). Nasri et al. (2013) agreed with these results, also reporting a peak of shoot induction from alstroemeria aerial explants when using $1 \mathrm{mg} \mathrm{L}^{-1} \mathrm{BAP}$. According to Hutchinson et al. (2010), high levels of growth regulators inhibit optimal morphogenic responses in alstroemeria explants, possibly due to a negative feedback mechanism. Moreover, to increase in vitro explant induction, Pedraza-Santos et al. (2006) suggested the use of liquid medium since they observed the induction of a greater number of adventitious buds. Increased diffusion of ions and oxygen and thus increased absorption of nutrients by the explant, unlike gelled culture medium, could explain the effects of liquid medium.

\section{Regeneration of induced explants}

As previously mentioned, direct regeneration was observed after explant induction. All the explants that achieved regeneration produced only one shoot. These results differ from the results obtained by Nasri et al. (2013), who observed the development of adventitious buds reaching regeneration of up to 2.33 shoots per induced explant after 8 weeks. Furthermore, Pedraza-Santos et al. (2006) achieved 2.7 buds per explant after 4 weeks by supplementing the culture media with $\mathrm{KIN}\left(2.5 \mathrm{mg} \mathrm{L}^{-1}\right)$ and BAP $\left(1.5 \mathrm{mg} \mathrm{L}^{-1}\right)$ and growing the explants in complete darkness and $8^{\circ} \mathrm{C}$ for 15 days. On the other hand, Lin et al. (1998) observed higher organogenesis from young leaves excised closer to the apex $(82.5 \%)$ and a greatest number of shoots per explant (4.5).

Considering the results of this study and those obtained by other authors (Hoshino, 2008; Pumisutapon et al., 2011; Kyte et al., 2013), the best regeneration results of alstroemeria explants were obtained by supplementing the culture media with cytokinins. Furthermore, Seyyedyousefi et al. (2013) suggested that low concentrations of auxins (ANA) are also required for the development and growth of leaf primordia during the regeneration of alstroemeria explants.

Explants cultured with $1.0 \mathrm{mg} \mathrm{L}^{-1}$ BAP showed more growth and development of regenerated plants, for example in the number of leaves per stem (Table 5) and the shoot length (data not shown). Growth regulator supplementation during in vitro culture, such as TDZ $\left(2.2 \mathrm{mg} \mathrm{L}^{-1}\right)$, BAP (1 $\left.\mathrm{mg}^{-1}\right)$ and NAA $\left(0.1 \mathrm{mg}^{-1}\right)$, significantly increased the length of regenerated shoots obtained from A. aurantiaca 'Rosita' and the number of leaves (Hutchinson et al., 2010).

Cytokinins cause shoot induction by stimulating cell division and reducing apical dominance which, according to Seyyedyousefi et al. (2013), explains why higher BAP concentrations decrease in shoot length. Nasri et al. (2013) observed 7.3 and 10.7 leaves per explant from an Alstroemeria ligtu hybrid after 4 and 8 weeks, respectively, in medium supplemented with $1 \mathrm{mg} \mathrm{L}^{-1}$ BAP and 0.1 $\mathrm{mg} \mathrm{L}^{-1}$ AIB. These results are higher than those obtained in the present study, where 3.59 was the maximum number of leaves per explant (Table 4). However, it is also important to consider the effect of the genotype during regeneration.

\section{Effect of oxidation on explant regeneration}

For some explants, oxidation was observed, likely related to regeneration, as an increase in oxidation seems to reduce regeneration. Thus, $100 \%$ of oxidation observed in stems was related to poor regeneration (5\%). However, shoots showed only $2 \%$ oxidation and the highest regeneration rate (30\%) (Figure 4). Furthermore, considering that significant differences were observed among the explants in terms of oxidation rate, different susceptibilities of the explants to oxidation could be suggested. 


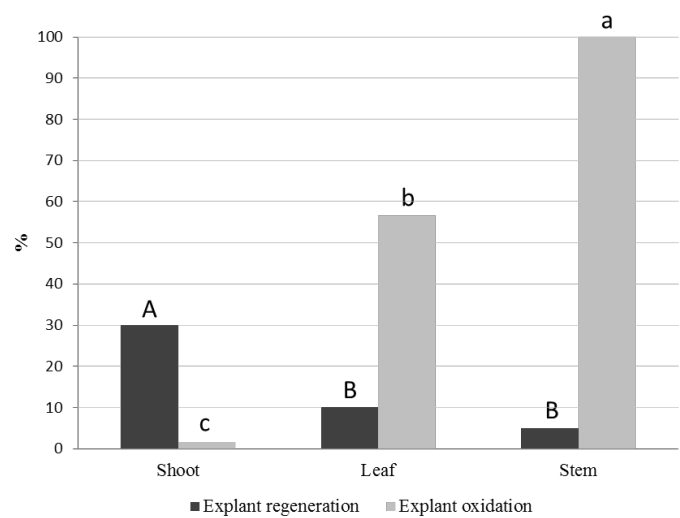

Figure 4. In vitro regeneration and oxidation of aerial explants of $A$. 'Sweet Laura' and A. caryophyllaea.

*Different capital letters indicate significant differences among explants for $\%$ of regeneration according to Tukey's test $(\mathrm{P} \leq 0.05)$.

**Different small letters indicate significant differences among explants for $\%$ of oxidation according to Tukey's test $(\mathrm{P} \leq 0.05)$.

The effect of oxidation on explant regeneration could be explained by energy accumulation when light absorption in leaf tissue exceeds the photosynthetic capacity of this organ, which subsequently produces reactive oxygen species and triggers photooxidative deterioration (Apel and Hirt, 2004). Lin et al. (1998) also observed browning in explants without regeneration, while no oxidation was observed by Pedraza-Santos et al. (2006) when growing in vitro explants in darkness.

Considering the promising results of this research, particularly for regeneration using shoots as explants, this protocol could be implemented for in vitro propagation of $A$. caryophyllaea and $A$. 'Sweet Laura' to avoid the limitations of in vivo propagation. Moreover, further studies should be conducted to adjust this protocol to other cultivars of alstroemeria.

\section{Acknowledgments}

This work was supported by FONDECYT Initiation into Research $N^{\circ} 11130325$, Government of Chile and U-inicia 2011, Vicerrectoría de Investigación y Desarrollo, University of Chile.

Special thanks to Pontificia Universidad Católica de Chile for providing plant material ( $A$. 'Sweet Laura') to conduct a portion of the experiments performed in this study.

\section{Resumen}

C. Guzmán, L. Prat, C. Rivas, y D. Aros. 2018. Inducción de organogénesis directa desde explantes aéreos de genotipos aromáticos de alstroemeria. Cien. Inv. Agr. 45(2): 158-168. Alstroemeria es una especie importante en el mercado de plantas ornamentales y flores de corte y su propagación es principalmente realizada por división de rizomas. Sin embargo, este método es ineficiente, altamente demandante de tiempo y puede contribuir a la dispersión de virus. Este estudio tuvo como objetivo desarrollar un protocolo de propagación in vitro usando explantes aéreos de Alstroemeria caryophyllaea y A. cv. 'Sweet Laura', dos genotipos aromáticos. Los explantes aéreos de alstroemeria fueron regenerados probando tres tipos de explantes y cuatro concentraciones de citoquininas. Tanto $A$. caryophyllaea como $A$. cv. 'Sweet Laura' mostraron la mayor tasa de inducción desde brotes, con valores de 35 y 63,3\%, respectivamente. Para ambos genotipos la concentración óptima de BAP para desarrollar organogénesis directa desde brotes fue de $1.0 \mathrm{mg} \mathrm{L}^{-1}$. Finalmente, se generó un protocolo exitoso para la propagación in vitro de A. caryophyllaea y A. cv. 'Sweet Laura' a partir de explantes aéreos.

Palabras clave: Alstroemeria caryophyllaea, Alstroemeria cv. 'Sweet Laura', cultivo de tejidos, reguladores de crecimiento. 


\section{References}

Akutsu, M., and H. Sato. 2002. Induction of proembryos in liquid culture increases the efficiency of plant regeneration from Alstroemeria calli. Plant Science, 163(3):475-479.

Apel, K., and H. Hirt. 2004. Reactive oxygen species: metabolism, oxidative stress, and signal transduction. Annual Review Plant Biology 55:373-399.

Aros, D., N. Spadafora, M. Venturi, G. Núñez-Lillo, C. Meneses, L. Methven, C.T. Müller, and H.J. Rogers. 2015. Floral scent evaluation of segregating lines of $A$. caryophyllaea. Scientia Horticulturae 185:183-192.

Aros, D., S. Valdés, E. Olate, and R. Infante. 2012a. Gamma irradiation on Alstroemeria aurea $\mathrm{G}$. in vitro rhizomes: An approach to the appropriate dosage for breeding purposes. Rev. FCA UNCUYO 44(1):191-197.

Aros, D., V. Gonzalez, R.K. Allemann, C.T. Müller, C. Rosati, and H.J. Rogers. 2012b. Volatile emissions of scented Alstroemeria genotypes are dominated by terpenes, and a myrcene synthase gene is highly expressed in scented Alstroemeria flowers. Journal of Experimental Botany 63(7):2739-2752.

Aros, D., M. Vásquez, C. Rivas, and M. L. Prat. 2017. An efficient method for in vitro propagation of Alstroemeria pallida Graham rhizomes. Chilean Journal of Agricultural Research.

Bayer, E. 1987. Die gattung alstroemeria in Chile. Mitteilungen der Botanischen Staatssammlung München 24:79-83.

Bridgen, M., E. Kollman, and C. Lu. 2009. Interspecific hybridization of alstroemeria for the development of new ornamental plants. Acta Horticulturae 836:73-78.

Burchi, G., A. Mercuri, C. Bianchini, L. Guglieri, and T. Schiva. 1997. Breeding of Alstroemeria through interspecific crosses and embryo-rescue. Colture Protette 9:113-118.

Chiari, A., and M.P. Bridgen. 2000. Rhizome splitting: a new micropropagation technique to increase in vitro propagule yield in alstroemeria. Plant Cell, Tissue and Organ Culture 62:39-46.

Cruz, I., A. Angarita, and T. Mosquera. 2003. Induc- tion of somatic embryogenesis in Alstroemeria spp. Agronomía Colombiana 21(3):121-128.

George, E.F., M.A. Hall, and G.J. De Klerk. 2008. Micropropagation: uses and methods. In Plant propagation by tissue culture (pp. 29-64). Springer Netherlands.

Hamidoghli, Y., S. Bohloli, and A. Hatamzadeh. 2007. In vitro propagation of Alstroemeria using rhizome explants derived in vitro and in pot plants. African Journal of Biotechnology. 6(18).

Hoshino, Y. 2008. Advances in alstroemeria biotechnology. Floriculture, Ornamental and Plant Biotechnology 5:540-546.

Hutchinson, M.J., J.M. Tsujita, and P.K. Saxena. 1994. Callus induction and plant regeneration from mature zygotic embryos of a tetraploid Alstroemeria (A. pelegrina $\times A$. psittacina). Plant cell reports, 14(2-3):184-187.

Hutchinson, M.J., R. Onamu, L. Kipkosgei, and S.D. Obukosia. 2010. Effect of thidiazuron, NAA and BAP on in vitro propagation of Alstroemeria aurantiaca $\mathrm{cv}$. 'Rosita' from shoot tip explants. The Journal of Agriculture, Science and Technology 12(2):60-69.

Khaleghi, A., A. Khalighi, and A. Sahraroo. 2008. In vitro propagation of Alstroemeria cv. 'Fuego'. American-Eurasian Journal of Agricultural and Environmental Sciences. 3(3):492-497.

Kim, J. B., C.J. Raemakers, E. Jacobsen, and R.G.F. Visser. (2006). Efficient somatic embryogenesis in Alstroemeria. Plant cell, tissue and organ culture. 86(2):233-238.

Kyte, L., J. Kleyn, H. Scoggins, and M. Bridgen. 2013. Plants from tubes: an introduction to micropropagation, $4^{\text {th }}$ edition. Portland, Oregon: Timber Press, Inc. 269p.

Lin, H.S., M.J. De Jeu, and E. Jacobsen. 1997. Direct shoot regeneration from excised leaf explants of in vitro grown seedlings of Alstroemeria L. Plant Cell Reports 16:770-774.

Lin, H.S., M.J. De Jeu, and E. Jacobsen. 1998. Formation of shoots from leaf axils of alstroemeria: the effect of the position on the stem. Plant Cell, Tissue and Organ Culture 52: 165-169.

Lin, H.S., C. Van Der Toorn, K.J.J.M. Raemakers, R.G.F Visser, M.J. De Jeu, and E. Jacob- 
sen. 2000. Development of a plant regeneration system based on friable embryogenic callus in the ornamental alstroemeria. Plant Cell Reports 19:529-534.

Lu, C., and M. Bridgen. 1996. Effects of genotype, culture medium and embryo developmental stage on the in vitro responses from ovule cultures of interspecific hybrids of alstroemeria. Plant science 116(2):205-212.

Lu, C., and M. Bridgen. 1997. Chromosome doubling and fertility study of Alstroemeria aurea X A. caryophyllaea. Euphytica 94:75-81.

Muñoz, M. and A. Moreira. 2003. Alstroemerias de Chile. Santiago, Chile

Murashige, T., and F. Skoog. 1962. A revised medium for rapid growth and bioassays with tobacco tissue cultures. Physiologiae Plantarum $15: 473$

Nasri, F., S.N. Mortaza, N. Ghaderi, and T. Javadi. 2013. Propagation in vitro of Alstroemeria ligtu hybrid through direct organogenesis from leaf base. Journal of Horticultural Research. 21(2): 23-30.

Ongaro, V., and O. Leyser. 2008. Hormonal control of shoot branching. Journal of Experimental Botany 59(1):67-74.

Pedraza-Santos, M.E., M.C. López-Peralta, V.A. González-Hernández, E.M. Engleman-Clark, and P. Sánchez-García. 2006. In vitro regeneration of Alstroemeria cv. 'Yellow king' by direct organogenesis. Plant Cell, Tissue and Organ Culture 84:189-198.
Prat, L., C. Botti, T. and Fichet. 2008. Effect of plant growth regulators on floral differentiation and seed production in jojoba (Simmondsia chinensis (Link) Schneider). Industrial Crops and Products 27:44-49.

Przybyla, A. 2000. Mutagenesis in creation of new Alstroemeria genotypes. Acta Horticulturae, 508:351-356.

Pumisutapon, P., R.G.F. Visser, and G.J. De Klerk. 2011. Hormonal control of the outgrowth of axillary buds in alstroemeria cultured in vitro. Biologia Plantarum 55(4): 664-668.

Seyyedyousefi, S.R., B. Kaviani, and N.P. Dehkaei. 2013. The effect of different concentrations of NAA and BAP on micropropagation of alstroemeria. European Journal of Experimental Biology 3(5):133-136.

Takayuki, I. 1999. Amphidiploids between Alstroemeria ligtu L. hybrid and A. pelegrina L. var. Rosea induced through colchicine treatment. Journal of Food and Agriculture 22(12):12-16.

Van Zaayen, A. 1995. Virus and Virus-like diseases of bulb and flower crops. West Sussex, UK.

Van Schaik, C. E., A. Posthuma, M.J. De Jeu, and E. Jacobsen. 1996. Plant regeneration through somatic embryogenesis from callus induced on immature embryos of Alstroemeria spp. L. Plant cell reports. 15(5):377-380.

Yousef, H., B. Sahar, and H. Abdollah. 2007. In vitro propagation of alstroemeria using rhizome explants derived in vitro and in pot plants. African Journal of Biotechnology 6(18): 2147-2149. 